九州大学学術情報リポジトリ

Kyushu University Institutional Repository

\title{
Allelopathic Suppression of Sorghum bicolor (L. ) Moench Shoot Extracts on Weed Germination and on Weeds Treated by Foliar Application
}

\section{LE, Thi Hien}

Science for Bioproduction Environment, Faculty of Agriculture, Kyushu University | Department of Crop Science, Chungnam National University

$\mathrm{OH}$, Taek-Keun

Science for Bioproduction Environment, Faculty of Agriculture, Kyushu University I Department of Bio-Environmental Chemistry, Chungnam National University

WON, Ok Jae

Science for Bioproduction Environment, Faculty of Agriculture, Kyushu University I Department of Crop Science, Chungnam National University

SHINOGI, Yoshiyuki

Science for Bioproduction Environment, Faculty of Agriculture, Kyushu University I Department of Bioproduction Environmental Sciences, Faculty of Agriculture, Kyushu University

他

https://doi.org/10.5109/1909898

出版情報: 九州大学大学院農学研究院紀要. 63 (1)，pp.21-25，2018-02-27. Faculty of Agriculture， Kyushu University

バージョン :

権利関係 : 


\title{
Allelopathic Suppression of Sorghum bicolor (L.) Moench Shoot Extracts on Weed Germination and on Weeds Treated by Foliar Application
}

\author{
Thi Hien LE ${ }^{1, \dagger}$, Taek-Keun OH $^{2, \dagger}$, Ok Jae WON ${ }^{1}$, Yoshiyuki SHINOGI ${ }^{3}$, Jeung Ju Lee ${ }^{4}$, \\ Kee Woong PARK ${ }^{1, *}$ and Jung-Sung CHUNG ${ }^{5, *}$
}

\author{
Science for Bioproduction Environment, Faculty of Agriculture, Kyushu University, Hakozaki 6-10-1, \\ Higashi-ku, Fukuoka city 812-8581, Japan \\ (Received October 30, 2017 and accepted November 20, 2017)
}

\begin{abstract}
This study aims to determine the contents of phenolic compounds from sorghum shoot extracts by fractional extraction in different solvents (ethanol, ethanol-chloroform, ethanol-hexane, ethanol-ethyl acetate, and ethanol-methylene chloride) and to assess their weed control efficacy. Results showed that the highest total amount of phenolic compounds was extracted using the solvent 'ethanol-ethyl acetate'. In order to assess allelopathy activity for potential weed management purposes, a bioassay was performed with four weed species including Abutilon avicennae, Digitaria sanguinalis, Amaranthus retroflexu, and Echinochloa crus-galli. A germination study indicated that all sorghum extracts had an inhibitory effect on all four-weed species. Bioassay results showed that, the extract obtained by ethanol-ethyl acetate solvent was more effective than other extracts (ethanol, ethanol-chloroform, ethanol-hexane, and ethanol-methylene chloride). In this work, the identification of the best extraction method from sorghum using different solvents could possibly lead to the development of an environmentally friendly natural herbicide for a more sustainable agriculture.
\end{abstract}

Key words: natural herbicide, phenolic compounds, Sorghum, weed control

\section{INTRODUCTION}

Allelopathy is defined as "any direct or indirect harmful or beneficial effect by one plant (including microorganisms) on another through production of chemical compounds that escape into the environment" (Rice, 1974). It refers to the release of certain compounds with promoting or inhibitory effects. These compounds are mostly secondary metabolites produced by plants during metabolic processes (Bhowmik and Inderjit, 2003). They inhibit stomatal movement and respiration, internode elongation, alter biomass partitioning to the leaves, and strongly interfere with the germination and growth of neighboring flora in several ways (Muhammad and Majeed, 2014).

Many plant species possess the capability to produce and release allelochemicals to suppress the growth of other plants (Weston, 1996). Among them, sorghum (Sorghum bicolor L. Moench.) is a potent and allelo-

\footnotetext{
Department of Crop Science, Chungnam National University, Daejeon 34134, Korea

Department of Bio-Environmental Chemistry, Chungnam National University, Daejeon 34134, Korea

Department of Bioproduction Environmental Sciences, Faculty of Agriculture, Kyushu University, Hakozaki 6-10-1, HigashiKu, Fukuoka City 812-8581, Japan

${ }^{4}$ Department of Plant Medicine, IALS, Gyeongsang National University, Jinju 52828, Korea

5 Department of Agricultural Plant Science, IALS, Gyeongsang National University, Jinju 52828, Korea

These two authors contributed equally to this work and should be considered co-first authors

* Corresponding author (E-mail: parkkw@cnu.ac.kr) (K.W. Park)

* Corresponding author (E-mail: jschung@gnu.ac.kr ) (J. Chung)
}

pathic crop whose allelochemicals and allelopathic effects on crops and weeds are well documented (Cheema and Khaliq, 2000). All parts of the sorghum plant such as roots, leaves, and stems as well as germinating seeds release phyto-inhibitors that can affect weed growth. Chemical constituents of sorghum include tannins, phenolic acids, anthocyanins, phytosterols, and policosanols (Awika \& Rooney 2004). Among these chemicals, phenolic acids have been most frequently identified as the phytotoxin (Blum 1996). A literature review indicates that water extracts of different plant parts of potential allelopathic crops can have significantly different suppressive effects on the growth of weeds (Ashraf \& Akhlaq 2007). Water extract of matured sorghum plants were used by Cheema and Khaliq (2000), and they reported that water extract spray application reduced weed biomass by $35-40 \%$ and increased wheat yield by $10-21 \%$. Sorghum root exudates reduced growth of various weed species at very low concentrations (Roth et al., 2000).

The objectives of this study were (i) to analyze the phenolic compound contents in sorghum, and (ii) to study the allellopathic suppression of sorghum shoot extracts on weed germination and on weeds treated by foliar application.

\section{MATERIALS AND METHODS}

\section{Plant materials}

At full stage, a sorghum cultivar named Donganme was harvested from the National Institute of Crop Science, Jeonju, Korea in 2016. After the collection, the sorghum was dried at Chungnam National University. The dried shoots were chaffed into $2-3 \mathrm{~cm}$ segments and then crushed and powderized by blender machine. 


\section{Sorghum shoot extraction}

A schematic diagram of the extraction method is shown in Figure 1. Firstly, sorghum powder was soaked in ethanol for 24 hours at room temperature and shaken to form a solid-liquid mixture, followed by the filteringout of the solid residue from the mixture to obtain a solution. The solution was divided into five volumeequal parts and the solvent was completely evaporated. Secondly, the mixtures remaining post evaporation were extracted by dissolving them into different solvent/distilled water 50:50, including chloroform $\left(\mathrm{CHCl}_{3}\right)$, hexane $\left(\mathrm{C}_{6} \mathrm{H}_{14}\right)$, ethyl acetate $\left(\mathrm{C}_{2} \mathrm{H}_{5}-\mathrm{OOC}-\mathrm{CH}_{3}\right)$, and methylene chloride $\left(\mathrm{CH}_{2} \mathrm{Cl}_{2}\right)$. These solutions were separated into two liquid phases, in which the polar phase was removed. The solvent remaining in the non-polar phase was completely evaporated and finally dissolved with distilled water for quantitative analysis of the total phenolic content by HPLC. Finally, five extracts of sorghum from five solvent systems were obtained including ethanol, ethanol-chloroform, ethanol-hexane, ethanol-ethyl acetate, and ethanol-methylene chloride, which were referred to as 'ethanol', 'ethanol-chloroform', 'ethanol-hexane', 'ethanol-ethyl acetate', and 'ethanol-methylene chloride', respectively.

\section{High-performance liquid chromatography (HPLC) analysis of phenolic compounds}

The five extracts of sorghum including 'ethanol', 'ethanol-chloroform', 'ethanol-hexane', 'ethanol-ethyl acetate', and 'ethanol-methylene chloride' were analyzed by HPLC. HPLC quantification of phenolic compounds was performed using a Futecs model NS-4000 HPLC apparatus. The analysis was monitored at $280 \mathrm{~nm}$ and performed using a C18 column $(250 \mathrm{~mm} \times 4.6 \mathrm{~mm}$, $5 \mu \mathrm{m})$. The mobile phase consisted of acetonitrile and $0.15 \%$ acetic acid under gradient conditions. Column temperature was set at $30^{\circ} \mathrm{C}$. The flow rate was set at $1.0 \mathrm{~mL} / \mathrm{min}$ and the injection volume was $20 \mu \mathrm{L}$. The quantities were calculated using a standard curve. All samples were run in triplicate.

\section{Effect of different sorghum shoot extract on weeds} Study of germination test under laboratory conditions

To study the effectiveness of sorghum shoot allelopathic properties for germination inhibition, four weed species including: Echinochloa crus-galli (Ec), Digitaria sanguinalis (Ds), Abutilon avicennae (Aa), and Amaranthus retroflexus (Ar) were tested for germination with different concentrations $(1 \mathrm{~g} / \mathrm{mL}, 0.5 \mathrm{~g} / \mathrm{mL}$, and $0.25 \mathrm{~g} / \mathrm{mL})(1 \mathrm{~g} / \mathrm{mL}: 1 \mathrm{~g}$ dry-weight sorghum-equivalent per $1 \mathrm{~mL}$ extract) of the extracts including 'ethanol', 'ethanol-chloroform', 'ethanol-hexane', 'ethanol-ethyl acetate', and 'ethanol-methylene chloride'. Different concentrations of the aforementioned extracts were diluted with distilled water at several volume ratios. The experiment was conducted as follows: ten weed seeds were placed into one petri dish $(60 \times 15 \mathrm{~mm})$ with two filter papers (Hyundai 10,50 mm). Five $\mathrm{mL}$ of extracts at different concentrations were added into each petri dish, sealed by parafilm. After that, they was kept in the growth chamber (for 8 hours under dark condition/ 16 hours under illuminated conditions, $25^{\circ} \mathrm{C} / 30^{\circ} \mathrm{C}$ ). The control was treated with distilled water only. The experiment was carried out in triplicate. After one week, inhibition of germination was checked and evaluated.

Study of foliar application under greenhouse conditions

All five prepared extracts ('ethanol', 'ethanol-chloroform', 'ethanol-hexane', 'ethanol-ethyl acetate', and 'ethanol-methylene chloride') were tested on four weed species Echinochloa crus-galli (Ec), Digitaria sanguinalis (Ds), Abutilon avicennae (Aa), and Amaranthus retroflexus (Ar). Weeds were grown in the green house $\left(25 \pm 5^{\circ} \mathrm{C}\right)$. Each type was separately grown in one cup in triplicate. When $2-3$ weed leaves appeared, the sorghum extracts were sprayed on these weeds. One week after spraying, the shoot of each weed
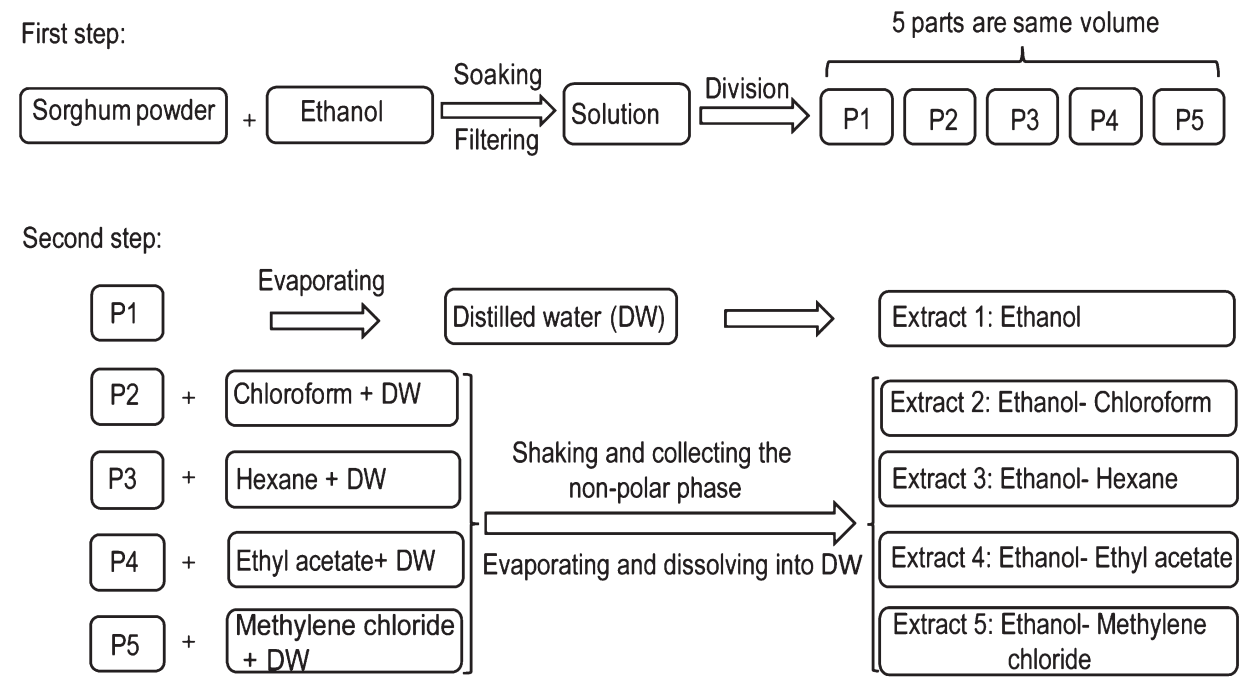

Fig. 1. Schematic diagram of phenolic compounds extraction from Sorghum shoots with different solvents (ethanol, ethanol-chloroform, ethanol-hexane, ethanol-ethyl acetate, and ethanol-methylene chloride). 
species was collected for biomass determination.

\section{RESULTS AND DISCUSSION}

\section{Analysis of the phenolic compound contents in sor- ghum extracts}

Chemical analysis of the extracts ('ethanol', 'ethanol-chloroform', 'ethanol-hexane', 'ethanol-ethyl acetate', and 'ethanol-methylene chloride') by HPLC indicated the presence of several phenolic acids including 4-hydroxybenzoic acid, chlorogenic acid, caffeic acid, Pcoumaric acid, ferulic acid, and kaempferol (Table 1).

The results showed that weed numbers and growth were more inhibited by sorghum cultivars with higher amount of 4-hydroxybenzoic acid and p-coumaric acid in their residues. However, the role of other phytotoxins in sorghum residues cannot be excluded. The significant growth reduction of companion weeds indicated that allelopathy may be the causative factor responsible for the reduction in growth and population of weeds observed in stands of the test sorghum genotypes with competition probably accentuating its effect. The results led to the conclusion that different sorghum cultivars had different allelopathic potential and that the exploitation of cultivars with higher allelopathic capacity would be of value for weed control. Especially, sorghum shoot extract in 'ethanol-ethyl acetate' had the highest amount of phenolic compounds in the cultivar. Additionally, the biggest amount of 4-hydroxybenzoic acid and P-coumaric acid, was also found in sorghum extract by solvent 'ethanol-ethyl acetate'.

\section{Study of germination test under laboratory condi- tions}

The germination test was performed on four weed species including Echinochloa crus-galli (Ec), Digitaria sanguinalis (Ds), Abutilon avicennae (Aa), and Amaranthus retroflexus (Ar) as shown in Table 2. Result from the study revealed that almost all weeds were sensitive to shoot extracts containing phenolic com-

Table 1. Isolation and quantification of phenolic compounds in sorghum shoot extracts by different organic solvents

Unit: $\mathrm{mg} / \mathrm{g}$

\begin{tabular}{|c|c|c|c|c|c|}
\hline \multirow[b]{2}{*}{ Phenolic compounds } & \multicolumn{5}{|c|}{ Organic solvent } \\
\hline & Ethanol & $\begin{array}{l}\text { Ethanol - } \\
\text { Chloroform }\end{array}$ & $\begin{array}{l}\text { Ethanol - } \\
\text { Hexane }\end{array}$ & $\begin{array}{l}\text { Ethanol - } \\
\text { Ethyl acetate }\end{array}$ & $\begin{array}{l}\text { Ethanol - } \\
\text { Methylene chloride }\end{array}$ \\
\hline 4-hydroxybenzoic acid & $2.55 \pm 0.18$ & $0.60 \pm 0.04$ & $1.25 \pm 0.07$ & $3.75 \pm 0.18$ & $0.10 \pm 0.06$ \\
\hline Chlorogenic acid & $0.17 \pm 0.01$ & $0.25 \pm 0.01$ & $0.25 \pm 0.00$ & $0.25 \pm 0.00$ & $0.25 \pm 0.01$ \\
\hline Caffeic acid & $0.05 \pm 0.00$ & $0.05 \pm 0.00$ & $0.05 \pm 0.00$ & $0.07 \pm 0.00$ & $0.05 \pm 0.00$ \\
\hline p-coumaric acid & $0.53 \pm 0.02$ & $0.18 \pm 0.01$ & $0.32 \pm 0.01$ & $0.80 \pm 0.02$ & $0.31 \pm 0.02$ \\
\hline Ferulic acid & $0.02 \pm 0.01$ & $0.03 \pm 0.00$ & $0.03 \pm 0.00$ & $0.04 \pm 0.00$ & $0.04 \pm 0.00$ \\
\hline Kaempferol & $0.01 \pm 0.01$ & $0.00 \pm 0.00$ & $0.02 \pm 0.00$ & $0.01 \pm 0.00$ & $0.02 \pm 0.00$ \\
\hline Total & $3.34 \pm 0.21$ & $1.11 \pm 0.04$ & $1.91 \pm 0.08$ & $4.92 \pm 0.18$ & $1.66 \pm 0.08$ \\
\hline
\end{tabular}

Table 2. Inhibition of germination in weed species as affected by different concentrations of sorghum shoot ex

\begin{tabular}{|c|c|c|c|c|c|c|}
\hline \multirow{2}{*}{$\begin{array}{c}\text { Weed } \\
\text { species }\end{array}$} & \multirow{2}{*}{$\begin{array}{l}\text { Concent- } \\
\text { ration } \\
(\mathrm{g} / \mathrm{mL})\end{array}$} & \multicolumn{5}{|c|}{ Sorghum extract in various solvents } \\
\hline & & Ethanol & $\begin{array}{l}\text { Ethanol - } \\
\text { Chloroform }\end{array}$ & $\begin{array}{l}\text { Ethanol - } \\
\text { Hexane }\end{array}$ & $\begin{array}{l}\text { Ethanol - } \\
\text { Ethyl acetate }\end{array}$ & $\begin{array}{l}\text { Ethanol - } \\
\text { Methylene chloride }\end{array}$ \\
\hline \multirow{3}{*}{$\begin{array}{l}\text { Abutilon } \\
\text { Avicennae }\end{array}$} & 1 & $100.0 \pm 0.00$ & $96.7 \pm 0.58$ & $96.7 \pm \pm 0.58$ & $100.0 \pm 0.00$ & $93.3 \pm 0.58$ \\
\hline & 0.5 & $90.0 \pm 0.00$ & $83.3 \pm 0.58$ & $76.7 \pm 2.31$ & $93.3 \pm 0.58$ & $83.3 \pm 0.58$ \\
\hline & 0.25 & $50.0 \pm 1.73$ & $40.0 \pm 1.73$ & $46.7 \pm 2.08$ & $50.0 \pm 1.73$ & $53.3 \pm 0.58$ \\
\hline \multirow{3}{*}{$\begin{array}{l}\text { Digitaria } \\
\text { sanguinalis }\end{array}$} & 1 & $100.0 \pm 0.00$ & $100.0 \pm 0.00$ & $100.0 \pm 0.00$ & $100.0 \pm 0.00$ & $100.0 \pm 0.00$ \\
\hline & 0.5 & $77.8 \pm 0.00$ & $59.3 \pm 2.08$ & $55.6 \pm 1.00$ & $85.2 \pm 1.53$ & $51.9 \pm 1.15$ \\
\hline & 0.25 & $63.0 \pm 1.53$ & $55.6 \pm 1.00$ & $44.4 \pm 1.73$ & $70.4 \pm 0.58$ & $44.4 \pm 1.00$ \\
\hline \multirow{3}{*}{$\begin{array}{l}\text { Amaranthus } \\
\text { retroflexu }\end{array}$} & 1 & $100.0 \pm 0.00$ & $100.0 \pm 0.00$ & $100.0 \pm 0.00$ & $100.0 \pm 0.00$ & $100.0 \pm 0.00$ \\
\hline & 0.5 & $100.0 \pm 0.00$ & $100.0 \pm 0.00$ & $100.0 \pm 0.00$ & $100.0 \pm 0.00$ & $100.0 \pm 0.00$ \\
\hline & 0.25 & $62.1 \pm 2.31$ & $55.2 \pm 1.15$ & $44.8 \pm 0.58$ & $75.9 \pm 1.15$ & $48.3 \pm 1.00$ \\
\hline \multirow{3}{*}{$\begin{array}{l}\text { Echinochloa } \\
\text { crus-galli }\end{array}$} & 1 & $83.3 \pm 0.58$ & $73.3 \pm 0.58$ & $63.3 \pm 0.58$ & $86.7 \pm 0.58$ & $73.3 \pm 2.08$ \\
\hline & 0.5 & $40.0 \pm 1.00$ & $33.3 \pm 2.08$ & $40.0 \pm 1.00$ & $50.0 \pm 1.00$ & $26.7 \pm 0.58$ \\
\hline & 0.25 & $20.0 \pm 1.00$ & $33.3 \pm 2.08$ & $20.0 \pm 0.00$ & $36.7 \pm 0.58$ & $16.7 \pm 0.58$ \\
\hline
\end{tabular}


pounds. As reported by Weston et al., 1989, 4-hydroxybenzoic acid is known for being a most potent and effective allelochemical. In addition, $\mathrm{p}$-coumaric acid is also a strong inhibitor of seed germination (Weston et al.,1989, Rimando et al., 2001). This is completely consistent with our results from Table 1 , in which the total amount of 4-hydroxybenzoic acid and p-coumaric acid of the extract by ethanol-ethyl acetate had the highest concentration showing that shoot extracts by ethanol-ethyl acetate was the most effective (Table 2). Moreover, the effect of all extracts increased at higher concentrations. The percentage of inhibitory effect on germination of the three weed species (Aa, Ds, and Ar) at $1 \mathrm{~g} / \mathrm{mL}$ concentration was $100 \%$ and $86.7 \%$ for Ec. In addition, the percentage of inhibitory effects on germination at $0.25 \mathrm{~g} / \mathrm{mL}$ concentration decreased by $50.0 \%$ (Aa), 70.4\% (Ds), 75.9\% (Ar), and 36.7\% (Ec).

\section{Study of foliar application under greenhouse con- ditions}

To further investigate the allelopathic activities for potential weed management purposes, all extracts ('ethanol', 'ethanol-chloroform', 'ethanol-hexane', 'ethanolethyl acetate', and 'ethanol-methylene chloride') were tested on weeds as shown in Figure 2. All tested chemical solvent extracts (Non-polar phase) of sorghum shoots significantly inhibited the weed growth. Results showed that in all treatments, extracts from sorghum in 'ethanol-ethyl acetate' had the highest effect on weed and the total weed biomass was significantly reduced compared to that of the control (Figure 2). The sorghum extracted by 'ethanol-ethyl acetate' had the most effect on weeds at $1 \mathrm{~g} / \mathrm{mL}$ concentration of the extract (75.59\% in Aa, 83.87\% in Ds, 84.37\% in Ar, and 32.26\% in Ec). In this study, 'ethanol-ethyl acetate' extracts of sorghum shoot caused the greatest inhibition of weeds growth, hence, 'ethanol-ethyl acetate' proved best extraction solvent to obtain the maximum yield of phenolic compounds from sorghum shoots.

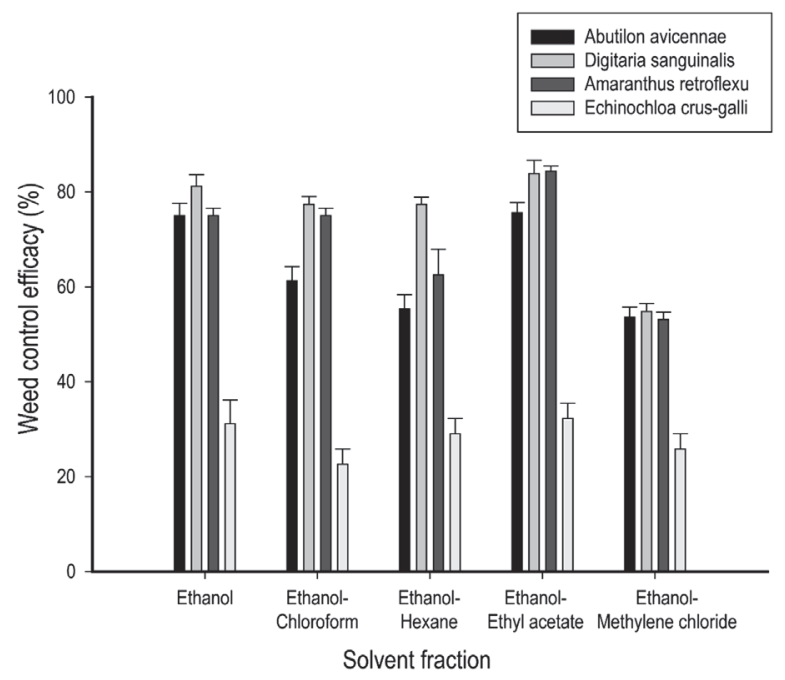

Fig. 2. Efficacy of sorghum shoot extracts at $1 \mathrm{~g} / \mathrm{mL}$ concentration on the growth of different weed species.

\section{CONCLUSIONS}

This study provided evidence that sorghum extracts can potentially be used as biological herbicides. The results of the germination test and bioassay in greenhouse proved that sorghum extracts were enabling the reduction of seed germination, growth, and development of weeds, aided by phenolic compounds of extracts. Indeed, this study established a phenolic compound extraction method in sorghum namely Donganme cultivar in different solvents (ethanol, ethanol-chloroform, ethanol-hexane, ethanol-ethyl acetate, and ethanol-methylene chloride). Among them, shoot extracts from sorghum by ethanol-ethyl acetate performed the best in partitioning the phenolic compounds (especially high content of 4-hydroxybenzoic acid and p-coumaric). Aqueous shoot extracts of sorghum from all solvents also exhibited high percentage of inhibitory effects on germination of different weed species, Echinochloa crus-galli (Ec), Digitaria sanguinalis (Ds), Abutilon avicennae (Aa), and Amaranthus retroflexus (Ar).

Hence, the study determined the basic for the allelopathic potential of sorghum in weed management. Furthermore, additional studies are required to evaluate the herbicidal efficacy of sorghum shoot extracts against different weed species before these methods can widely be applied and recommended to farmers for use. If proven to be an efficient method of weed management and adopted successfully, it can lead to significant accomplishments in the development of sustainable agriculture.

\section{AUTHOR CONTRIBUTIONS}

Thi Hien LE and Taek-Keun OH carried out substantial contribution to the concept and design on this paper. Ok Jae WON, and Jeung Ju Lee carried out analysis and interpretation of data. Yoshiyuki SHINOGI verified the data. Jung-Sung CHUNG and Kee Woong PARK supervised the project and wrote the paper. All authors commented on the manuscript.

\section{ACKNOWLEDGEMENTS}

This work was carried out with the support of the "Cooperative Research Program for Agricultural Science \& Technology Development" (Project No. PJ011307012017), Rural Development Administration, Republic of Korea.

\section{REFERENCES}

Awika, J. M. and L. W. Rooney 2004 Sorghum phytochemicals and their potential impact on human health. Elsevier, 65: 11991221

Ashraf, M., and M. Akhlaq 2007 Effects of sorghum leaves, roots and stems water extract, hand weeding and herbicide on weeds suppression and yield of wheat. Sarhad J. Agric., 23 (2): 319-327

Bhowmik P. C. and Inderjit 2003 Challenges and op- Kuiters A. T. and Sarink H. M. 1986, Leaching of pheportunities in implementing allelopathy for natural nolic compounds from leaf and 
needle litter of several weed management. Crop Protec., 22: 661-671

Blum, U., 1996. Allelopathic interactions involving phenolic acids. J. Nematol., 28: 259-267

Cheema, Z. A. and A. Khaliq 2000 Use of sorghum allelopathic properties to control weeds in irrigated wheat in a semi-arid region of Punjab. Agric. Ecosys. and Environ., 79: 105-112

Muhammad Z, A. Majeed 2014 Allelopathic effects of aqueous extracts of sunflower on wheat (Triticum aestivum L.) and maize (Zea mays L.). Pak J Bot., 46(5): 1715-1718

Rice, E. L. 1974. Allelopathy. Academic Press, New York, p. 353 Roth, C. M., J. P. Shroyer, and G. M. Paulsen 2000 Allelopathy of sorghum on wheat under several tillage systems. Agron. J. 92: $855-860$

Weston, L. A 1996 Utilization of allelopathy for weed management in agroecosystems. Agron. J., 88: 860-866 